\title{
DISCOURSE-BASED SYLLABUS FOR TEACHING LITERATURE TO EFL LEARNERS IN VIETNAM
}

\author{
Tran Thi Ngoc Lien \\ Haiphong Private University, Vietnam \\ email: lienttn@hpu.edu.vn
}

\begin{abstract}
This paper focuses on the potential use of discourse analysis in literature teaching in EFL class as well as approaches to designing discourse-based syllabus. This non-conventional approach has radically changed the teaching culture at Haiphong Private University, Vietnam which used to consider the analysis of literary works as reading comprehension lesson. Using this novel syllabus has gradually formed a so-called $3 \mathrm{D}$ (imention) class in which the teacher talks, the students talk and the literary text talk from its properties and as a result the ultimate objectives of literature teaching, say, language competence and literary appreciation can be achieved. Also, some parts of the sample syllabus are shared with a hope that they will be of certain benefit to readers.
\end{abstract}

Key words: syllabus, literature teaching, discourse, discourse analysis

\section{SILABUS BERBASIS WACANA UNTUK MENGAJAR SASTRA PADA PEMBELAJAR BAHASA INGGRIS SEBAGAI BAHASA ASING DI VIETNAM}

\begin{abstract}
Abstrak: Makalah ini focus pada penggunaan analisis wacana yang potensial pada pengajaran sastra di kelas bahasa Inggris sebagai bahasa Asing (EFL) dan juga pendekatan-pendekatan untuk merancang silabus berbasis wacana. Pendekatan yang tidak biasa ini telah benar-benar mengubah budaya mengajar di Haiphong Private University, Vietnam, yang sebelumnya biasa menganggap analisis karya sastra sebagai pelajaran membaca. Penggunaan silabus baru ini telah secara bertahap membentuk apa yang disebut kelas 3D(imention), dimana guru berbicara, mahasiswa berbicara dan karya sastra berbicara dari sifat-sifatnya, sehingga tujuan-tujuan utama pengajaran sastra, misalnya kompetensi bahasa dan penghargaan terhadap sastra bias dicapai. Selain itu, beberapa bagian dari contoh silabus tersebut dibagikan dengan harapan bisa bermanfaat bagi para pembaca.
\end{abstract}

Kata kunci: Silabus, pengajaran sastra, wacana, analisis wacana

Literature as defined in Bouman, 1996 cited in Mishan (2005:105) is "a form of art with two creators, one being the author, who, with his linguistic competence and his subtle, creative power of words, sparks the imagination, the creative power of the other, the reader".Therefore, teaching and learning such a form of arts is a tough job especially to L2 teachers whose ultimate duty is to transport literary canon to their learners in a foreign language.

There remains a question regarding how literature has been taught so far. From the traditional pedagogy of "getting it right" (at the beginning stages of Latin and Greek), students of literature were instructed to mimic their teachers' knowledge and injunctions. Towards the latter part of the nineteenth and much of 
the twentieth century, students in literature classes were still taught as if their job was to 'get it right'. However, the concept of "right" then was extended to the right interpretations and meanings which come from instructors but not from the independent thinking and active engagement of learners. Today, it is obvious that literature teaching course attaches more importance to the objective of assisting teachers to help students think more critically about the value of literary study as well as provoking teachers of literature to realize the outcomes of their course.

What is expected from teaching literature is therefore no longer confined to teaching reading or analyzing literary textual properties such as syntax, lexis or semantics but what teachers of literature expect in the learning outcomes are growth of mind, enlargement of self, personal and intellectual development, emotional engagement, representations of culture, social values and experiences, and many more. It is, thus, a big challenge to achieve such outcomes if teachers still inhabit the pedagogic framework of teaching literature as reading comprehension; literature course designers are inclined to the syllabus design for language teaching and learners' endeavor to parrot their instructors. An answer to this question may come from the attempt to adopt discourse-based syllabus for a literature course motivated by the recent viewpoint which highlights literature as discourse. Therefore, the writer of this article would like to share her experience in teaching literature with discourse-based syllabus to EFL learners and how it actually works in the context of tertiary class in Vietnam.

\section{Literature as a Discourse}

When discourse analysis has grown to be prevalent as the study of how stretches of language take on meaning, purpose, and unity for their users, a significant proportion of the interest has focused on literature as discourse.

The motivation for literary discourse study is not only the potential to augment our understanding of discourse in general but also the relevance to pedagogy. In fact, our conceptions of literature are bound to influence the way in which we teach it. Discourse analysis has focused on the social nature of communication, highlighting the contextual aspects of meaning which are interactive and negotiated, determined by social relations and identities of the participants in communication. This approach makes up a consensus that literature is primarily a mode of interaction, reflecting and creating its own institutions and power relations. There is nothing distinctive about the language of literary discourse or its representations of the world. The importance of viewing literature as a type of discourse is enlightened in Todorov's:

there is no longer any reason to confine to literature alone the type of studies crystallised in poetics: we must read 'as such' not only literary texts but all, not only verbal production, but all symbolism. (Todorov, 1981: 71)

\section{A footnote to Todorov's statement reads:}

Our teaching still privileges literature to the detriment of all other types of discourse. We must be aware that such a choice is purely ideological and has no justification in the phenomena themselves. Literature is inconceivable outside a typology of discourses.

Obviously, literature with its diverse literary genres ranging from novels to short stories, from poetry to fictional works can actively contribute to the panoramic view of discourse. It is advisable that a literary work be analyzed both from its own literary context and as a part in discourse process. 
Fowler's approach (Fowler, 1981) stresses the interpersonal dimension of literature, same as Hallidayan view that the function of all discourse is a blend of the interpersonal and ideational. From within a broadly sociolinguistic framework he examines writers' use of language in so far as linguistic choices reflect and influences relations with society. Following theories outlined in Halliday (1978), Fowler gives attention to the sociolinguistic varieties or registers of language and examines how they crystallize in a range of literary texts in response to the social, economic, technological and theoretical needs of the cultures concerned. A particular focus emerges, too, on the linguistic relations produced by the text between authors and readers; these will in turn encode, according to Fowler, the determining socio-economic structures of particular historical contexts.

There is a dialectical interrelationship between language and social structure: the varieties of linguistic usage are both products of socioeconomic forces and institutions-reflexes of such factors as power relations, occupation roles, social stratifications, etc., and practices which are instrumental in forming and legitimating these same social forces and institutions. The New Critics and the Formalists vehemently denied that 'literature' had social determinants and social consequences, but a sociolinguistic theory...will show that all discourse is part of social structure and entersinto...effected and effecting relationships...(Fowler, 1981:21)

In terms of linguistic properties, Fowler [ibid: 21] argues that there is no special variety of language use which is distinctively or exclusively literary:

Some of the varieties used in the constitution of a specific 'literary' text may tend to occur regularly in some, but not all, other 'literary' texts but they are not restricted to 'literary' texts (rhyme and alliteration are found in advertisements); and 'literary' texts also draw upon patterns which tend to occur in 'nonliterary' texts (conversation, news report). This stylistic overlapping and the absence of any necessary and sufficient linguistic criterion for the 'literary' text, is well known though often ignored. My suggestion is that stylistics and literary studies must take sociolinguistic variety theory and methodology seriously as a way of accounting for the specific linguistic properties of the texts concerned (Fowler, 1981, p. 21).

Formalist theories of literary language may attempt to isolate 'literary' language, but such language use can be found in social discourses which are not institutionally defined as literary. And this, for Fowler, would be further evidence of the paradoxes inherent in not seeing literature as social discourse.

Added to the teaching literature, Carter and Long (1991) contrasts a view of literature as text with literature as discourse. From the view of traditional literary education, literature is decontextualised 'words on the page'. The discourse view, however, significantly more akin to the later twentieth century thinking, requires from learners active interpretations in contexts. They emphasized that a view of language as discourse consider it a form of social action, that we "do things with words" (Austin, 1975). Discourses are 'ways of being in the world, forms of life' (Gee, 1996: viii). Engaging with discourses we signal and discover who and what we are in given contexts of communication, 'making sense' of ourselves, of others and of our worlds through our communicative resources, formulating or reformulating ideas, beliefs and values and our relations with one another.

In a useful review of the provenance and concerns of discourse studies, Jaworski\&Coupland (1999) highlights a set of defining parameters focused on by those 
who study discourse in its varied manifestations. First, they argue that discourse implies not simply an interest in meaning, 'language in use', but also a much wider and more ambitious interest in all the determinants 'beyond language in use'.

\section{Syllabus and Syllabus Design: a Brief Review}

There is disagreement regarding what a syllabus is. Hutchinson and Waters (1987) generally define syllabus, at its simplest level, a statement of what is to be learnt. It reflects language and linguistic performance. Widdowson who focuses more on the process of syllabus design is of the opinion that a syllabus is "the framework of activities and becomes a threat to pedagogy when it is regarded as absolute rules for determining what is to be learned rather than points of reference" (Widdowson, 1984:26). By this definition, we understand that syllabi are flexible and changeable. However, Allen proposes a definition to some extent contradictory to Widdowson in that syllabus is "the selection of materials based on objectives, duration of course, and level" (Allen, 1984: 64). These definitions though different have the same focal point in that a syllabus is designed for a specific objective to be achieved and showing how to achieve it.

In fact, a suitable syllabus is a secure for effective learning and positive outcome of the learning process. Therefore discussions often come up as what types of syllabus work with what kinds of class and controversies have hovered around the two main ones: product-oriented with focus of the structural-grammatical syllabus, the semantico-notional syllabus, the situational and the functional; and process-oriented with the core of the task-based syllabus (Nunan, 2004), the learner-centered syllabus (Breen, 1984), or the proportional syllabus (Yalden, 1984 ).

Whether these types of syllabi ideally fit in a literature learning course is still open to argument. Facts indicate that outcomes of literature teaching course may vary as literary canon itself is 'a loose, baggy monster, a fluid movement of ebbs and flows, ins and outs - imaginary, therefore, as opposed to concrete' Gallagher (2001: 54). Also, literature appreciation is also different from learner to learner. For example, how much a high school student with great motivation takes in from the course will not be for sure the same as does a 40 year old learner feeling stressful with heavy workload or parenthood. Therefore, there should be one thing concrete about teaching literature: the syllabus. She proposes that the syllabus is the list of works that are frequently taught in the classroom, 'a list that is empirically verifiable'. Guillory (1993: 28) concurs with the view that "An individual's judgment that a work is great does nothing in itself to preserve that work, unless that judgment is made in a certain institutional context, a setting in which it is possible to insure the reproduction of the work, its continual reintroduction to generations of readers."

Whatever type of syllabus is adopted in a literature teaching class, it should be separately designed and ideally describe:

1. What the learners are expected to know at the end of the course, or course objectives in operational terms.

2. What is to be taught or learned during the course, in the form of an inventory items.

3. When it is to be taught, and at what rate of progress, relating the inventory of items to the different levels and stages as well as to the time constraints of the course.

4. How it is to be taught, suggesting procedures, techniques, and materials

5. How it is to be evaluated, suggesting testing and evaluating mechanisms.

(Dubin\&Olshtain, 1996:28)

Discourse-based Syllabus for Literature Teaching to EFL learners 


\section{Syllabus content}

Same as the definition and classification, syllabus content has received much attention and opinions diverge regarding what should be the focus of a syllabus. Nunan (1998:137) states that a syllabus needs to clearly address the "aim, resources, procedure, and evaluation", while Mills (2006:13) highlights more requirements with "title, objectives, background, problem statement, procedures, resources, as well as assessment."

A syllabus for literature teaching, which is not an exception, also comprises course objectives, procedure, resources and assessment. However the difference lies in that course objectives in literature teaching are not limited to the mastery of linguistic structure and certain linguistic usage. In fact, a course is designed to the security of both language and literary competence. Shafieyan (2011) states "in English Teaching, courses are more often than not teacher-oriented and text-based, yet English Literature usually lends itself to be managed by self-study with different approaches in literary criticism that are not restricted to text-based methods, but reader-response orientation, historical or author-intended meaning, psychological approaches, and so forth." Therefore it is important that an L2 literature teaching syllabus is designed to promote learners' literary competence "the ability to infer a message" (Carter \& Long, 1991:4) alongside with language competence. To some extent, these two tasks cannot be easily separated because literary competence is only achievable when L2 learners are capable of comprehending language use.

Working with literature as discourse, syllabus designers and language practitioners need to think over the two interdependent aforementioned course objectives as well as the resources which help to achieve both. Regarding the former, learners are expected to develop the ability to read, think, converse, and write critically about various literary works while for the latter, it is important thatthey be able to communicate their appreciation of the works assigned and develop the skills of analysis, synthesis, and evaluation.

To achieve these objectives, on the one hand, discourse structure with its own linguistic elements such as cohesion, information structure, genre and discourse properties including coherence, speech acts, implicature, so on and so forth will be placed for analysis from bottom-up approach. By this way, literature is not constrained to separate analysis of sentence grammar and meaning but beyond the language in use.As Butler (1999) reckons, literature is of a discourse type in which "how the message is conveyed is as important, if not more, than the message itself" Butler [ibid: 34]. On the other hand, particular meanings especially literary nuances will be inferred from discourse components by top-down processing. The syllabus designed needs to make social identifications communicate.

\section{Approaches to discourse-based syllabus design}

Once the major content of a syllabus has been set, the task that remains should be how to compose it. In teaching literature with a discourse-bases syllabus, to achieve the objective of language competence, both a synthetic and an analytic approach are made use of. Wilkins (1976) suggested that for the former approach,

"different parts of the language are taught separately and step by step so that acquisition is a process of gradual accumulation of the parts until the whole structure of the language has been built up", whereas the latter supports the fact that "learning can be focused on important aspects of the language structure ...[as] components of the language are not seen as building blocks which have to be progressively accumulated ... Significant 
linguistic forms can be isolated from the structurally heterogeneous context in which they occur (Wilkins, 1976).

Let us start with analytic or bottom up approach. Discourse structure with its own rules is open for analysis: the opening with its formation of theme and its linguistic properties; the development, say, constituent skeleton of a prose or rhythmic principle of a verse and the ending with coda or morale, for example. What is placed for emphasis is the relevance between discourse structure, linguistic components and literary appreciation. This means that learners are required to identify how rules of language in a discourse structure create meanings. For example, it is necessary to place in a syllabus the requirement of exploring not simply what sentence type is dominant in the text or how conjunctions are frequent but why "and" is presented in high frequency in fairy tale. The explanation comes because it iscoordinating conjunction or in other words cohesive device "and" typicalizes the narrative genre and is used to create cohesion of the invented events. Another example is explanation for the use of simple, short sentences in characters' dialogue in Hemingway's short stories. In fact, this linguistic means is made use of to create story climax and characterizes the author's stamp. Similarly, lexical analysis is often treated in reference to context and the constraints of discourse range. Take the analysis of the excerpt "Strong Temptation - Strategic Movements - The Innocents Beguiled" in The Adventure of Tom Sawyer written by Mark Twain as an example. No one can deny the effect created by the lexical chain with its cohesion in the opening paragraph of the text (referring to the brightening summer day) in contrast to what is used to describe Tom's low spirit (tackling the burden of whitewashing a thirty yards of board-fence nine feet high) in the paragraph that follows. The contrasting themes brought about by semantic field help reader-learners realize the intended meaning of that literary text as well as writer's intention.

As far as synthetic or top down approach is considered, learners are expected to sense from the literary theme the aesthetic and artistic effect of language in use, consider the context to realize why certain discourse properties are presented, or base on the interactional function of language to account for specific literary significances. In fact, extra linguistic elements presented in a literary discourse often accompany with themselves certain message. A short story, for instance, can be interpreted from the investigation into three parts of narration, digression, and representation. A poem can be better appreciated thanks to an in-depth insight into rhythm, meter, rhyme, or poetic devices such as metaphor, irony, hyperbole or linguistic properties like lexical reiteration, synonymy, or antonymy. The analysis of such aspects as turn-taking, cooperative principle, politeness maxims, and so forth are likely to better learners' understanding of Hamlet, one play of Shakespeare's. Take the case of the short story "Hills like the white elephants" written by Hemingway. The story will be of nothing to be mentioned if learners are required to analyze its linguistic components only. In this case, to grasp fully literary appreciation, it is better to start with the umbrella theory of conversation analysis and then detailed investigation into the dialogues between two protagonists. In fact, it is not the plot or setting, the character or theme that reveals much of literary signification as the whole story revolved around two characters' conversations. Analyses reveal that flouts of conversation maxims in the characters' dialogues illuminate not only interpersonal relations between two protagonists but also characters' self and social identity; the deviations of politeness strategy push up story climax; and the analysis of conversation structures 
manifests Hemingway's writing style: story lies in no story at all.

Another approach we would like to suggest is the interactive. In teaching literature, reader-response theory should be promoted as reading is not a direct 'internalisation'.It is also not a one way process', but 'a dynamic interaction between text and reader' (Iser, 1980: 107). As reckoned in Bouman (1996) as cited in Mishan (2005) that literature is "a form of art with two creators, one being the author, who, with his linguistic competence and his subtle, creative power of words, sparks the imagination, the creative power of the other, the reader", it is necessary to motivate learners to interact to the text and the world in which the text is created. And as Long (1991: 53-9) goes on to point out that the most useful types of response to literature for the teacher to cultivate are the creative responses to come out of interaction (individual or group) with and about the text. In this way, the ability of a literary work to engage the emotions can have the useful corollary of its potential for exploitation at the interpersonal level. Learners accordingly will be able to develop their interpretation, evaluation and communication of literary significance together with the task of literary-textual analysis.

\section{Using discourse-based syllabus}

Discourse-based syllabus is designed not to replace the conventional one but to make full of the discourse dimension in analyzing a literary text in an attempt to enhance learners' language competence and literary competence. To help it work effectively, it is better to familiarize both teachers and learners with the syllabus. First, teachers need to equip themselves with sufficient knowledge about discourse analysis and its application in evaluating an artistic prosaic text. Second, they should take an active role in orienting the learners to the discourse interpretation and its relevance to literary appreciation. Beware that students should not be required to study and practice discourse analysis but learn how to interpret and appreciate a literary work from its typical discourse features. It is apparent that analyzing conversation structure in character's discourse in prosaic texts in light of discourse analysis is dissimilar to using knowledge of discourse in interpreting literary value. A discourse analyst is, say, expected to have an in-depth insight into relevant discourse properties such as how language is used in conversation, how conversation works under the principle of turn taking, or how maxims of politeness are compromised. A teacher of literature, however, is the person who helps students figure out the underlying literary significance from the working structure of conversation. Third, as literary texts vary in length, difficulty, genre, and signification, informing learners with course timeline and requirements in advance is also advisable.

As regards learners, they should be well prepared for the course by mastering the course objectives and approaches. Due to time constraints and variations in learners' prior knowledge, learners are required to have adequate resources for their course: information about their teachers, materials, learning strategies, etc. which help ensure the lesson manageability.

Active learning should be also encouraged as learners need to know how to work independently and this method is even more important in learning process as literary appreciation of each learner evidently differs in length, intensity, or wisdom.

\section{Sampling}

Facts indicate what is included in a syllabus will be determined by students' needs, the rationale and type of the course, and the philosophy underlying the course. A discourse-based syllabus for literature teaching to EFL learners is not an 
exception. However, to make the course effective it is incumbent upon course designers to fulfill the tasks that follow:

- Describe the course, including its goals and objectives

- Outline the structure of the course and its significance within the general program of study (particularly any nonconventional aspects which may be new to the students)

- Discuss the obligations that both teachers and the students share for learning outcomes, for the activities and processes of learning, and for respecting the behavioral codes valued by the teacher, the program, and the campus

- Give a clear explanation of assessment and evaluation practices - that is, how teachers will provide feedback on how well students have been achieving and meeting the course goals and objectives

- State out clearly the course requirements as well as course policies and expectations

- Provide critical, logistic and procedural information about what will happen, when it will happen, and where it will happen, including activities and assignments

(Adapted from O'Brien, Millis \& Cohen, 2008)

In the following section, we would like to sample some parts of a discourse-based syllabus which is currently in use in teaching English and American literature to EFL learners in Haiphong Private University, Vietnam.

\section{Course Description}

This course is about teaching English and American literature to EFL learners who will be taught how to analyze selected literary works of three main genres: novel, short stories and poems by using knowledge of discourse analysis.

Lessons about literature are delivered to learners in a non-conventional approach which requires them to work more closely with literature as discourse as it is assumed that a good understanding of literary discourse can help much in literary appreciation. The learning process is highly interactive in that learners are required to involve in this process not only as learners but also analysts, critical thinkers, writers, and sometimes characters. Also, this is a process in which "the text talks" but not just "the learners talk". Literary appreciation is not reflected purely from learners' subjective opinions but also textual properties

What makes discourse-based syllabus discrepant is the way teachers and learners work with literary texts. On the one hand, working top-down can augment our critical analysis of language use in literary texts. Such linguistic components as cohesion or coherence contribute greatly to students' understanding of lexical expressions, the way of using words in each literary text or genre or grammatical structures of not singly a correct sentence but also the underlying relations between them. Treated as social discourse, literary texts tell us much about the social and cultural identity on which they are constructed. On the other hand, a bottom-up approach to literary discourse triggers students' critical thinking over the umbrella significance of a literary work. Analyses of how conversation maxims are violated in O'Henry's short story "The gift of Magi" reveal much more about the story theme than just the task of Q and A about plot. It is a more important approach to literary appreciation than the analysis of linguistic structures only. Another example is the analysis of politeness phenomenon in the fabricated dialogues between the old man and the fish in "The old man and the sea" written by Hemingway. The deviation of polite strategies tells much about writer's intention, structure of that short story, and its characterization.

All what have been disclosed in the above-mentioned features of the course will be provided in this term length course. 
After being provided with skills of analysis, synthesis, as well $\mathrm{s}$ evaluation, students will be more confident with their literary appreciation and language comprehension. The requirements of working collaboratively or doing course project will be of great importance for them to enhance their active learning.

\section{Course Objectives}

After the course, the student should be able to ...

1. Develop students' appreciation of selected works of American literature
2. Assist students in analyzing selected works of literature using knowledge of discourse analysis and reflecting/conversing/ writing about them as both individual and collaborative learners

3. Help students develop skills of reflection, analysis, synthesis, and evaluation in their reading, writing, and thinking

4. Appreciate the relationship of literature to social

life

Detailed Course Outline

\begin{tabular}{|c|c|c|c|c|c|c|}
\hline No & Literary work & Genre & $\begin{array}{c}\text { Time } \\
\text { allotment } \\
\text { (period }= \\
45 \text { ') }\end{array}$ & $\begin{array}{l}\text { Classroom } \\
\text { activities }\end{array}$ & $\begin{array}{l}\text { Discourse } \\
\text { Analysis }\end{array}$ & What to be mastered \\
\hline 1 & $\begin{array}{l}\text { Hamlet } \\
\text { By Shakespeare }\end{array}$ & Play & 3 & Discussion & $\begin{array}{l}\text { Conversati } \\
\text { on analysis }\end{array}$ & $\begin{array}{l}\text { Language focus: Colloquial } \\
\text { speech patterns and idiom } \\
\text { Literary appreciation: Power } \\
\text { of Love } \\
\text { Intercultural discussion: } \\
\text { Social prejudice; class } \\
\text { discrimination; love }\end{array}$ \\
\hline 2 & $\begin{array}{l}\text { Waiting for } \\
\text { Godot } \\
\text { By Samuel Beckett }\end{array}$ & Play & 3 & Discussion & $\begin{array}{l}\text { Ideological } \\
\text { structure }\end{array}$ & $\begin{array}{l}\text { Language focus: Descriptive } \\
\text { language } \\
\text { Literary appreciation: Social } \\
\text { impact and Religious belief } \\
\text { Intercultural discussion: } \\
\text { Cold war between Ireland } \\
\text { and Britain } \\
\text { Religious parable }\end{array}$ \\
\hline 3 & $\begin{array}{l}\text { The Snapper } \\
\text { By Roddy Doyle }\end{array}$ & Play & 3 & Role play & $\begin{array}{l}\text { Phatic } \\
\text { communic } \\
\text { ations }\end{array}$ & $\begin{array}{l}\text { Language focus: Colloquial } \\
\text { speech patterns and idiom } \\
\text { Literary appreciation: Social } \\
\text { prejudice; Emotional } \\
\text { conflicts; } \\
\text { Intercultural discussion: } \\
\text { Prejudice in Irish society } \\
\text { toward unmarried pregnancy }\end{array}$ \\
\hline 4 & $\begin{array}{l}\text { At the Church } \\
\text { Gate } \\
\text { By William } \\
\text { Makepeace }\end{array}$ & Poem & 3 & $\begin{array}{l}\text { Group } \\
\text { work }\end{array}$ & $\begin{array}{l}\text { Metre and } \\
\text { Rhythm }\end{array}$ & $\begin{array}{l}\text { Language focus: Similar } \\
\text { sounds } \\
\text { Literary appreciation: Love } \\
\text { and its inspiration }\end{array}$ \\
\hline
\end{tabular}




\begin{tabular}{|c|c|c|c|c|c|c|}
\hline & Thackeray & & & & & $\begin{array}{l}\text { Intercultural discussion: } \\
\text { Love and the sacred faith }\end{array}$ \\
\hline 5 & $\begin{array}{l}\text { 'Song V' } \\
\text { By Christina } \\
\text { Georgina Rossetti }\end{array}$ & Poem & 3 & $\begin{array}{l}\text { Group } \\
\text { work }\end{array}$ & $\begin{array}{l}\text { Conversati } \\
\text { on analysis } \\
\text { Lexical } \\
\text { cohesion } \\
\text { Stressed } \\
\text { and } \\
\text { unstressed } \\
\text { syllables in } \\
\text { the end- } \\
\text { rhymes }\end{array}$ & $\begin{array}{l}\text { Language focus: } \\
\text { Interrogatives and } \\
\text { Negatives; Lexical chain } \\
\text { Literary appreciation: Tones } \\
\text { of threat and assertion; } \\
\text { Emotional conflicts } \\
\text { Intercultural discussion: } \\
\text { Interaction }\end{array}$ \\
\hline 6 & $\begin{array}{l}\text { Britain's Ida } \\
\text { By Edmund Spenser }\end{array}$ & Poem & 3 & Discussion & $\begin{array}{l}\text { Discourse } \\
\text { structure } \\
\text { Rhetorical } \\
\text { alexandrin } \\
\text { e creeps }\end{array}$ & $\begin{array}{l}\text { Language focus: Verb form } \\
\text { and meaning } \\
\text { Literary appreciation: Metre } \\
\text { and discourse } \\
\text { Intercultural discussion: } \\
\text { Love- a universal topic }\end{array}$ \\
\hline 7 & $\begin{array}{l}\text { Valentine Week } \\
\text { By Emily Dickinson }\end{array}$ & Poem & 3 & $\begin{array}{l}\text { Group } \\
\text { work }\end{array}$ & $\begin{array}{l}\text { Figurative } \\
\text { meaning }\end{array}$ & $\begin{array}{l}\text { Language focus: Figurative } \\
\text { meaning } \\
\text { Literary appreciation: } \\
\text { Oxymoron; Symbolism; } \\
\text { Emotional conflict } \\
\text { Intercultural discussion: } \\
\text { Love - Sentiments }\end{array}$ \\
\hline 8 & $\begin{array}{l}\text { Hills like the } \\
\text { White Elephants } \\
\text { By Earnest } \\
\text { Hemingway }\end{array}$ & $\begin{array}{l}\text { Short } \\
\text { story }\end{array}$ & 3 & Role play & $\begin{array}{l}\text { Implicature } \\
\text { Politeness } \\
\text { phenomen } \\
\text { on }\end{array}$ & $\begin{array}{l}\text { Language focus: Sentence } \\
\text { structure (Simple sentence) } \\
\text { Literary appreciation: } \\
\text { Deception and Trust; } \\
\text { Emotional conflicts; } \\
\text { Narrative techniques of } \\
\text { Hemingway in writing short } \\
\text { story } \\
\text { Intercultural discussion: } \\
\text { Love and its tragedy }\end{array}$ \\
\hline 9 & $\begin{array}{l}\text { A Rose for Emily } \\
\text { By Faulkner William }\end{array}$ & $\begin{array}{l}\text { Short } \\
\text { story }\end{array}$ & 3 & $\begin{array}{l}\text { Course } \\
\text { project }\end{array}$ & $\begin{array}{l}\text { Speech act } \\
\text { Irony } \\
\text { Sarcasm }\end{array}$ & $\begin{array}{l}\text { Language focus: Sentence } \\
\text { structure (Complex } \\
\text { sentence) } \\
\text { Literary appreciation: Irony } \\
\text { and } \\
\text { Intercultural discussion: } \\
\text { Love and its tragedy }\end{array}$ \\
\hline 10 & $\begin{array}{l}\text { The Gift of Magi } \\
\text { By O'Henry }\end{array}$ & $\begin{array}{l}\text { Short } \\
\text { story }\end{array}$ & 3 & $\begin{array}{l}\text { Group } \\
\text { work }\end{array}$ & $\begin{array}{l}\text { Word } \\
\text { meanings }\end{array}$ & $\begin{array}{l}\text { Language focus: Short } \\
\text { sentence } \\
\text { Literary appreciation: } \\
\text { Characterization; climax } \\
\text { Intercultural discussion: } \\
\text { Love and its magical power }\end{array}$ \\
\hline 11 & $\begin{array}{l}\text { To build a Fire } \\
\text { By Jack London }\end{array}$ & $\begin{array}{l}\text { Short } \\
\text { story }\end{array}$ & 3 & $\begin{array}{l}\text { Story- } \\
\text { telling }\end{array}$ & $\begin{array}{l}\text { Ideological } \\
\text { structure }\end{array}$ & $\begin{array}{l}\text { Language focus: Language } \\
\text { of narration } \\
\text { Literary appreciation: } \\
\text { Narration and story climax } \\
\text { Intercultural discussion: } \\
\text { Love and its tragedy }\end{array}$ \\
\hline 12 & $\begin{array}{l}\text { The Egg } \\
\text { By Sherwood } \\
\text { Anderson }\end{array}$ & $\begin{array}{l}\text { Short } \\
\text { story }\end{array}$ & 3 & $\begin{array}{l}\text { Story- } \\
\text { telling } \\
\text { Discussion }\end{array}$ & $\begin{array}{l}\text { Taxonomic } \\
\text { structure of } \\
\text { narrative }\end{array}$ & $\begin{array}{l}\text { Language focus: Language } \\
\text { of narration } \\
\text { Literary appreciation: } \\
\text { Emotional conflicts; Plot } \\
\text { and theme }\end{array}$ \\
\hline
\end{tabular}




\begin{tabular}{|c|c|c|c|c|c|c|}
\hline & & & & & & Intercultural discussion: \\
\hline 13 & $\begin{array}{l}\text { The Great Gatsby } \\
\text { By Fitzgerald, F. } S\end{array}$ & Novel & 3 & Discussion & $\begin{array}{l}\text { Lexical } \\
\text { chain } \\
\text { Cohesion }\end{array}$ & $\begin{array}{l}\text { Language focus: Language } \\
\text { of Description } \\
\text { Literary appreciation: } \\
\text { Intercultural discussion: } \\
\text { American obsession of } \\
\text { wealth }\end{array}$ \\
\hline 14 & $\begin{array}{l}\text { Farewell to Arms } \\
\text { By Earnest } \\
\text { Hemingway }\end{array}$ & Novel & 3 & $\begin{array}{l}\text { Pair work } \\
\& \\
\text { Group } \\
\text { work }\end{array}$ & $\begin{array}{l}\text { Interperson } \\
\text { al relation } \\
\text { Ideological } \\
\text { structure }\end{array}$ & $\begin{array}{l}\text { Language focus: Sentence } \\
\text { structure (Complex } \\
\text { sentence) } \\
\text { Literary appreciation: } \\
\text { Characterization; theme and } \\
\text { plot } \\
\text { Intercultural discussion: War } \\
\text { and Peace }\end{array}$ \\
\hline 15 & $\begin{array}{l}\text { The Sound and } \\
\text { the Fury } \\
\text { By Faulkner William }\end{array}$ & Novel & 3 & $\begin{array}{l}\text { Course } \\
\text { project }\end{array}$ & $\begin{array}{l}\text { Interperson } \\
\text { al relation } \\
\text { Implicature }\end{array}$ & $\begin{array}{l}\text { Language focus: } \\
\text { Vocabulary: form and } \\
\text { meaning } \\
\text { Literary appreciation: } \\
\text { Characterization; theme and } \\
\text { plot } \\
\text { Intercultural discussion: } \\
\text { Aristocratic family and } \\
\text { social conflicts }\end{array}$ \\
\hline
\end{tabular}

\section{CONCLUSION}

Discourse-based syllabus has actually had enormous impacts on the culture of teaching and learning English literature in EFL class in Haiphong Private University, Vietnam. It triggers a 3D(imension) class in which the teachers talk, the learners talk and the texts talk. Almost all students have positive feedback about the course as they realize their active role in learning process. Literature learning as what they reckon goes beyond the task of reading comprehension lessons. Literary appreciation has become more objective from the analysis of word, sentence, and other discourse properties. However, there are still challenges facing syllabus designers, language practitioners, teachers and learners. First, lack of knowledge about discourse analysis reduces course efficiency. It even becomes a bigger problem when discourse analysis is dropped out of the curriculum and thereby learners have no idea about what discourse is and what to do with discourse analysis. Second, there is not yet a consistent framework which determines what discourse properties are placed for analysis. In fact, typical discourse features which help disclose the underlying literary values vary from genre to genre, author to author, and text to text. The analysis therefore depends largely on teachers' competence and intention. These problems are open to further research so that our application of discourse-based syllabus in literature teaching for EFL class in Vietnam gains its true value.

\section{REFERENCES}

Allen, J. P. B., (1984). General purpose language teaching: A variable focus approach. In General English syllabus design. Ed. C. J. Brumfit. Oxford: Pergamon.

Austin, J.L. (1975).How to do things with words. Oxford: Oxford University Press.

Breen, M.P. (1984).Process syllabuses for the language classroom.In General English syllabus design.(Ed.) C. J. Brumfit. Oxford: Pergamon

Butler, I. (1999). Integrating language and literature.Folio, Journal of the 
Materials Development Association MATSDA.

Carter, R. \& Long, M. N. (1990).Teaching literature.Longman Handbooks for Language Teachers. Harlow: Longman.

Dubin, F.\&Olshtain, E. (1986).Course design.Cambridge: Cambridge University Press.

Gallagher, S.V. (2001). 'Contingencies and intersections: the formation of pedagogical canons', Pedagogyl(1), pp. 53-67

Fowler, R. (1981) Literature as social discourse: The practice of linguistic criticism. London: Batsford.

Gee, J. P. (1996). Social linguistics and literacies: Ideology in discourses. 2nd ed. London: Taylor \& Francis.

Guillory, J. (1993).Cultural capital: The problem of literary canon formation. Chicago: University of Chicago Press.

Halliday, M.A.K. (1978) Language as social semiotic. London: Edward Arnold

Hutchinson, T. \& Waters, A. (1987). English for specific purposes:A learning-centeredapproach. Cambridge University Press

Iser.W. (1980).The act of reading. Baltimore: The John Hopkins University Press.

Jaworski, A. \&Coupland, N. (eds.). (1999).The discourse reader. London: Routledge.

Long, M. (1991). 'A feeling for language: The multiple values of teaching literature', in: Brumfit, C.\& Carter, R.(eds.)Literature and language teaching. Oxford: Oxford University Press

Mills, C.S. (2006).Using the Internet for active teaching and learning. New Jersey: Pearson Education, Inc.

Mishan, F (2005).Designing authenticity into language learning materials. Bristol: Intellect

Nunan, D. (1998).Syllabus design.Oxford: Oxford University Press

Nunan, D. (2004).Task-based language teaching. New York: Cambridge University Press.

O’Brien, G.J., Millis, J.B. \&Cohen, W.M (2008).The course syllabus: Learningcentered approach. San Franscisco: Jossey-Bass.

Shafieyan, M. (2011). International conference on education, research and innovation IPEDR, 18 (2011) () (2011) IACSIT Press, Singapore

Todorov, T. (1981).Introduction to poetics.University of Minnesota Press.

Widdowson, H. G. (1984).Educational and Pedagogical Factors in Syllabus Design.In General English syllabus design.Ed. C. J. Brumfit. Oxford: Pergamom

Wilkins, D.( 1976).Notional syllabuses.Oxford: Oxford University Press.

Yalden, J. (1984). Syllabus design in general education. In General English syllabus design. Ed. C. J. Brumfit. Oxford:Pergamon 